\title{
DEPARTMENT OF ANAESTHESIA VANCOUVER HOSPITAL AND HEALTH SCIENCES CENTRE FELLOWSHIP POSITIONS
}

Applications are invited for the position of fellow, Department of Anaesthesia, Vancouver Hospital and Health Sciences Centre.

Twelve month positions offering clinical and research experience in the areas of thoracic and vascular anaesthesia, acute pain management, ambulatory care and neuromuscular blockade/antagonism are available July 1, 1997 and January 1, 1998.

Candidates considered for this position should be Fellows of the Royal College of Physicians and Surgeons of Canada prior to these commencement dates, and eligible for licensure in the province of British Columbia.

Salary and benefits are competitive.

$$
\begin{gathered}
\text { Applications and curriculum vitae should be submitted to: } \\
\text { Dr. David M. Ansley } \\
\text { Clinical Assistant Professor } \\
\text { Director of Research and Fellowship Programs } \\
\text { Department of Anaesthesia } \\
\text { Vancouver Hospital and Health Sciences Centre } \\
\text { Room 3200,910 West 10th Ave. } \\
\text { Vancouver, BC V5Z 4E3 }
\end{gathered}
$$

In accordance with the Canadian immigration requirements, this advertisement is directed to Canadian citizens and permanent residents in Canada.

Vancouver Hospital and the University of British Columbia is committed to equity in employment.

\section{THE DEPTS. OF ANESTHESIOLOGY OF \\ THE MOUNT SINAI SCHOOL OF MEDICINE OF THE CITY UNIVERSITY OF NEW YORK and \\ INSTITUTO NACTIONAL DE CARDIOLOGIA IGNACIO CHAVEZ, MEXICO, D.F.}

present the

\author{
15th Annual Symposium \\ CLINICAL UPDATE IN ANESTHESIOLOGY \\ And Advances in Techniques Of Cardiopulmonary Bypass \\ WITH INTERNATIONAL FACULTY AND INDUSTRIAL EXHIBITS \\ January 18-25, 1997 \\ Acapulco, Mexico
}

Free papers will be accepted for oral and poster presentation in four categories: (A) monitoring; (B) new pharmacological agents; (C) interesting case reports; (D) cardiopulmonary bypass technology. Abstract forms are available upon request. The deadline for submission is November 1, 1996. Tuition will not be waived.

Accreditation: The Page and William Black Postgraduate School of Medicine of the Mount Sinai School of Medicine (CUNY).

For information and abstract forms contact:

Helen Phillips

Box 1010, Mt. Sinai Medical Center

1 Gustave L. Levy Place, New York, NY 10029-6574

212-241-7630 Fax: 212-426-2009 